\title{
Treatment of lumbar curves in adolescent females affected by idiopathic scoliosis with a progressive action short brace (PASB): assessment of results according to the SRS committee on bracing and nonoperative management standardization criteria
}

\author{
AG Aulisa ${ }^{1 *}$, V Guzzanti ${ }^{1}$, C Perisano ${ }^{2}$, F Falciglia ${ }^{1}$, G Maggi ${ }^{3}$, L Aulisa ${ }^{3}$ \\ From 8th International Conference on Conservative Management of Spinal Deformities and SOSORT 2011 \\ Annual Meeting \\ Barcelona, Spain. 19-21 May 2011
}

\section{Background}

The effectiveness of conservative treatment of scoliosis is controversial. Some studies suggest that brace is effective in stopping curve progression, whilst others did not report such an effect.

The purpose of the present study was to effectiveness of PASB in the correction of lumbar curves, in agreement with the SRS Committee on Bracing and Nonoperative Management Standardisation Criteria [1][2].

\section{Materials and methods}

Fourty adolescent females (mean age $12.95 \pm 1.72$ years) with lumbar curve and a pretreatment Risser score ranging from 0 to 2 have been enrolled. The minimum duration of follow-up was 24 months (mean: $41.75 \pm$ 34.47 months). Antero-posterior radiographs were used to estimate the curve magnitude $(\mathrm{CM})$ and the torsion of the apical vertebra (TA) at 5 time points: beginning of treatment ( $\mathrm{t} 1$ ), one year after the beginning of treatment ( $\mathrm{t} 2)$, intermediate time between $\mathrm{t} 1$ and $\mathrm{t} 4 \mathrm{(t3)}$, end of weaning ( $t 4), 2$-year minimum follow-up from $t 4(t 5)$. Three situations were distinguished: curve correction, curve stabilisation and curve progression.

${ }^{1}$ Children Hospital Bambino Gesù, Rome, Italy

Full list of author information is available at the end of the article

\section{Results}

$\mathrm{CM}$ mean value was $26.43 \pm 2.77 \mathrm{SD}$ at $\mathrm{t} 1$ and $13.80 \pm$ 7.94 SD at t5. TA was $10.83 \pm 3.74$ SD at $\mathrm{t} 1$ and $7.88 \pm$ 4.24 at $\mathrm{t} 5$. The variation between measures of Cobb and Perdriolle degrees at $\mathrm{t} 1,2,3,4,5$ and between $\mathrm{CM} \mathrm{t} 5$ - $\mathrm{t} 1$ and TA t5-t1 were significantly different.

Curve correction was accomplished in $82.5 \%$ of patients, whereas a curve stabilisation was obtained in $17.5 \%$ of patients.

\section{Conclusions}

The PASB, due to its peculiar biomechanical action on vertebral modelling, is highly effective in correcting lumbar curves.

\section{Author details}

'Children Hospital Bambino Gesù, Rome, Italy. ${ }^{2} \mathrm{~A}$. Gemelli" Hospital, Università Cattolica del Sacro Cuore, Italy. ${ }^{3} \mathrm{~A}$. Gemelli Hospital, Università Cattolica del Sacro Cuore, Italy.

\section{Published: 27 January 2012}

\section{References}

1. Aulisa AG, Guzzanti V, Perisano C, Marzetti E, Menghi A, Giordano M, Aulisa L: Correlation between hump dimensions and curve severity in idiopathic scoliosis before and after conservative treatment. Spine (Phila Pa 1976) 2011.

2. Aulisa AG, Guzzanti V, Galli M, Perisano C, Falciglia F, Aulisa L: Treatment of thoraco-lumbar curves in adolescent females affected by idiopathic scoliosis with a progressive action short brace (PASB): assessment of 
results according to the SRS committee on bracing and nonoperative management standardization criteria. Scoliosis 2009, 4:21.

doi:10.1186/1748-7161-7-S1-026

Cite this article as: Aulisa et al: Treatment of lumbar curves in

adolescent females affected by idiopathic scoliosis with a progressive action short brace (PASB): assessment of results according to the SRS

committee on bracing and nonoperative management standardization criteria. Scoliosis 2012 7(Suppl 1):O26.

Submit your next manuscript to BioMed Central and take full advantage of:

- Convenient online submission

- Thorough peer review

- No space constraints or color figure charges

- Immediate publication on acceptance

- Inclusion in PubMed, CAS, Scopus and Google Scholar

- Research which is freely available for redistribution

Submit your manuscript at www.biomedcentral.com/submit 